\title{
Safety assessment and behavioral effects of Solanum guaraniticum leaf extract in rats
}

\author{
Gabriela Bonfanti ${ }^{1, *}$, Paula Eliete Rodrigues Bitencourt ${ }^{3}$, Karine Santos De Bona ${ }^{2}$, Luis Ricardo \\ Peroza $^{4}$, Lariane Oliveira Cargnelutti ${ }^{3}$, Raphaela Maleski Borges ${ }^{3}$, Aline Grohe Schirmer Pigatto ${ }^{5}$, \\ Roselei Fachinetto ${ }^{2,4}$, Aline Augusti Boligon ${ }^{2}$, Margareth Linde Athayde ${ }^{3}$, Thissiane de Lima \\ Gonçalves $^{2}$, Maria Beatriz Moretto ${ }^{2,3}$
}

${ }^{1}$ Centro de Ciências da Saúde e Agrárias, Universidade de Cruz Alta, UNICRUZ, Cruz Alta, RS, Brasil, ${ }^{2}$ Centro de Ciências da Saúde, Universidade Federal de Santa Maria, UFSM, Santa Maria, RS, Brasil, ${ }^{3}$ Centro de Ciências da Saúde, UFSM, ${ }^{4}$ Centro de Ciências Naturais e Exatas, UFSM, ${ }^{5}$ Centro Universitário Franciscano, UNIFRA, Santa Maria, RS, Brasil

\begin{abstract}
Solanum guaraniticum is a medicinal plant traditionally used to treat gastric and liver diseases. However, there is no documented evidence corroborating its safety. The present study evaluated the potential toxicity of $S$. guaraniticum leaf extract after acute administration in rats. Single doses of the extract $(1.250,2.500$, and $5.000 \mathrm{mg} / \mathrm{kg})$ were administered by gavage, and the rats were then monitored for $48 \mathrm{~h}$ and/or 14 days. Mortality, acute signs of toxicity, and general activity in the open field test were assessed as well as hematological and biochemical parameters, enzymatic activity ( $\delta$-aminolevulinate dehydratase and acetylcholinesterase), and oxidative stress parameters (lipid peroxidation level, nonprotein thiol content, tissue catalase activity, and serum ferrous reducing power). Phytochemical analysis was also performed by HPLC. The results showed that extract administration produced no deaths $\left(\mathrm{LD}_{50}>5,000 \mathrm{mg} / \mathrm{kg}\right)$, and no significant adverse effects regarding food consumption, body weight gain, gross pathology, or other parameters. However, the open field tests showed a decrease in spontaneous activity (crossing and rearing) mainly at $48 \mathrm{~h}$ after treatment. The results suggest that $S$. guaraniticum extract is not acutely toxic, but causes alterations in central nervous system activity.
\end{abstract}

Uniterms: Solanum guaraniticum/leaf extract/toxicity. Solanum guaraniticum/phytochemistry. Medicinal plants. Solanaceae.

Solanum guaraniticum é uma planta medicinal tradicionalmente usada para tratar doenças gástricas e hepáticas. Porém, não há evidências documentadas sobre sua segurança. O presente estudo avaliou a toxicidade do extrato das folhas de $S$. guaraniticum após administração aguda em ratos. Doses únicas do extrato $(1.250,2.500$ and $5.000 \mathrm{mg} / \mathrm{kg})$ foram administradas por gavagem e os animais foram monitorados por $48 \mathrm{~h}$ ou 14 dias. Mortalidade, sinais de toxicidade aguda e atividade geral, através do teste de campo aberto, foram analisados, assim como parâmetros hematológicos e bioquímicos, atividades enzimáticas ( $\delta$-aminolevulinato desidratase e acetilcolinesterase) e parâmetros de estresse oxidativo (nível de peroxidação lipídica, conteúdo de tióis não protéicos, atividade da catalase em tecidos e poder redutor em soro). A análise fitoquímica também foi realizada por HPLC. Os resultados mostraram que a administração do extrato não provoca mortes $\left(\mathrm{LD}_{50}>5.000 \mathrm{mg} / \mathrm{kg}\right)$ ou efeitos adversos significativos com relação ao consumo de comida, ganho de peso corporal, análise patológica, entre outros. Entretanto, o teste de campo aberto mostrou uma diminuição na atividade espontânea geral (cruzamentos e levantadas), principalmente em $48 \mathrm{~h}$ após o tratamento. Portanto, nossos resultados sugerem que o extrato de $S$. guaraniticum não é agudamente tóxico, mas causa alterações na atividade do sistema nervoso central.

Unitermos: Solanum guaraniticum/extrato de folhas/toxicidade. Solanum guaraniticum/fitoquímica. Plantas medicinais. Solanaceae.

\footnotetext{
*Correspondence: G. Bonfanti. Centro de Ciências da Saúde e Agrárias. Universidade de Cruz Alta - UNICRUZ. Campus Universitário Dr. Ulysses Guimarães. Rodovia Municipal Jacob Della Méa, Km 5.6 - Parada Benito 98020-290 - Cruz Alta - RS, Brasil. E-mail: gbonfanti@unicruz.edu.br
} 


\section{INTRODUCTION}

The consumption of medicinal plants has increased in recent years and has received much attention. According to the World Health Organization, between $70 \%$ and $90 \%$ of the world's population (primarily in developing countries), rely on plant-derived medicines for their healthcare (WHO, 2011). However, such traditional plants used for the treatment of diseases need further scientific investigation of their toxic side effects (WHO, 2008). Moreover, systematic toxicity studies, and especially pharmacological activity studies of these plants must be conducted in order to make their use safe and appropriate (Andrade, et al., 2012).

The Solanum genus is widely distributed throughout the world with approximately 1,400 species; it has a special importance to local economies, agriculture, and to the pharmaceutical sciences (Bohs, 2005). Of particular importance is Solanum guaraniticum A. St.-Hil, a yearlong flowering and fruiting shrub with broad and simple leaves, white flowers, and globose fruits that are yellow when ripe (Rech et al., 2006). The species occurs in Paraguay, Argentina, and Brazil (Stehmann et al., 2012), and is popularly known as "false-jurubeba". The tea from its leaves is used to treat anemias, fevers, spleen and liver diseases, and as a tonic and digestive stimulant (Costa, 1940; Simões et al., 1999).

Recent in vitro studies have demonstrated that Solanum guaraniticum leaf extract displays radical scavenger activity, and protective effects against oxidative injury in cells and tissues (Bonfanti et al., 2013, 2014; Zadra et al., 2012). The Brazilian Pharmacopoeia describes only $S$. paniculatum L. as the true jurubeba (Corrêa, 1984), yet interchangeable use of these two species by folk medicine is common.

Certain members of Solanaceae, including tomatoes potatoes and eggplants are known to contain varied steroidal glycol-alkaloids that are toxic to both humans and animals (Baker, Keeler, Gaffield, 1991; Jadhav, Sharma, Salunkhe, 1981). Yet there is paucity of pharmacological and toxicological data on such $S$. guaraniticum properties. Previous studies of a similar species, S. fastigiatum in high doses, have evidenced liver toxicity (Sabir, Rocha, 2008), which was also related to bovine intoxication, affecting the central nervous systems of the animals (Rech et al., 2006; Riet-Correa et al., 1983; Paulovich et al., 2002).

Toxicity in medicinal plants occurs at several levels in biochemical systems, and metabolic enzymes might well help for identification of these impairments. The enzyme acetylcholinesterase (AChE, EC 3.1.1.7) plays a major role in the regulation of several physiological events, and the activity of the cholinergic system is vital to normal behavior and muscular function (Schetinger et al., 2000; Payne et al., 1996). As such, the crucial role of this enzyme in neural transmission makes it a primary target for a large number of cholinesterase-inhibiting drugs and toxins (Pohanka, 2011), and a valuable diagnostic tool for verifying exposure to chemical agents (Shenouda, Green, Sultatos, 2009). The heme pathway enzyme deltaaminolevulinate dehydratase ( $\delta$-ALA-D, EC 4.2.1.24) presents high sensitivity to pro-oxidant situations, and to impairment of metabolic processes, thus being used to evaluate toxicity as well (Nogueira et al., 2003; Souza et al., 2009). Previous studies by our group have already demonstrated the inhibitory in vitro effects of $S$. guaraniticum extract on erythrocyte and brain $\delta$-ALA-D, suggesting possible extract caused hematological and central nervous systems impairments (Bonfanti et al., 2013, 2014).

Despite the popular use of $S$. guaraniticum for the treatment of various disorders, little scientific data is available regarding its safety, and there are no documented toxicological studies which can be used to ascertain safe dosages for its herbal preparations. The present study aimed to carry out an extensive acute toxicological evaluation of $S$. guaraniticum leaf extract in rats, including biochemical, hematological, and oxidative parameters, and also its effects on the general activity of the animals in an open-field test.

\section{MATERIAL AND METHODS}

\section{Plant material}

Leaves of S. guaraniticum were collected in the city of Santa Maria (Rio Grande do Sul, State of Brazil). The material was authenticated by Prof. Aline S. Pigatto, and a voucher specimen was deposited at the herbarium of the Federal University of Santa Maria (registration number: 12980). The leaves were dried in a greenhouse, smashed in a knife mill, and submitted to extraction with ethanol $80 \%$ in a Soxhlet apparatus until exhaustion. The extract was prepared at the proportion of $5 \mathrm{~g}$ of dried leaves to $100 \mathrm{~mL}$ of solvent. After extraction, the solvent was completely evaporated in a rotavapor system (Eidi, Eidi, Esmaeili, 2006), and analyzed by high-performance liquid chromatography (HPLC). Reverse phase chromatographic analyses were carried out under gradient conditions using a $\mathrm{C} 18$ column $(4.6 \mathrm{~mm} \times 250 \mathrm{~mm})$, packed with $5 \mu \mathrm{m}$ diameter particles. The mobile phases were: (A) acetonitrile:water $(95: 5, \mathrm{v} / \mathrm{v})$, and (B) water:phosphoric acid $(98: 2, \mathrm{v} / \mathrm{v})$, the composition gradient was: $5 \%$ of $\mathrm{A}$ 
until $10 \mathrm{~min}$, and changing to obtain $20 \%, 40 \%, 60 \%, 70 \%$ and $100 \% \mathrm{~A}$, at 20,30, 40, 50 and $60 \mathrm{~min}$, respectively. The flow rate was $0.7 \mathrm{~mL} / \mathrm{min}$, injection volume was $40 \mu \mathrm{L}$, and the wavelengths were $254 \mathrm{~nm}$ for gallic acid, $280 \mathrm{~nm}$ for catechin and epicatechin, $327 \mathrm{~nm}$ for chlorogenic, ellagic, and caffeic acids, and $365 \mathrm{~nm}$ for rutin, isoquercitrin, quercitrin, kaempferol and quercetin. The chromatographic peaks were confirmed by comparing their retention times with those of reference standards, and by DAD spectra (200 to $500 \mathrm{~nm})$.

\section{Animals}

Male adult albino Wistar rats (200-250 g) were maintained at $22 \pm 2{ }^{\circ} \mathrm{C}$ and on a 12-h light/dark cycle allowing adaptation to laboratory conditions for one week prior to the start of the experiment. The animals were divided according to dosages, in groups of three rats for each treatment; the treatments were duplicated with different animals. Tap water and a standard pellet diet were provided ad libitum throughout the experiment, except for the short fasting period where the drinking water was still free to access but no food supply was provided for $12 \mathrm{~h}$ prior to treatment. The animals were used according to the guidelines of the Committee on Care and Use of Experimental Animal Resources of the Federal University of Santa Maria, Brazil (Protocol 053/2012), and all efforts were made to minimize the number of animals used and their suffering.

\section{Study design}

Acute oral toxicity of the $S$. guaraniticum leaf extract was evaluated based on the procedures outlined by the Organization for Economic Co-operation and Development with minor modifications (OECD, 2001, 2008; Rosidah et al., 2009; Hor et al., 2011). Following the $12 \mathrm{~h}$ fast, the extracts (suspended in water) were administered by oral gavage at single doses of 1.250 , 2.500 and $5.000 \mathrm{mg} / \mathrm{kg}$ to the respective groups $(\mathrm{n}=6)$. Six animals received distilled water and were regarded as the control group. All treatments were administered at $5 \mathrm{~mL} / \mathrm{kg}$ body weight.

Food was provided again to the rats approximately one hour after treatment. Visual observations: for mortality, behavioral pattern changes such as aggressiveness, food or water refusal, diarrhea, salivation, discharge from the eyes and ears, noisy breathing, changes in locomotor activity, piloerection, tremors, convulsion, coma, injury, pain, or any signs of illness in each treated group were monitored continuously for the first $4 \mathrm{~h}$ after dosing, and periodically until $48 \mathrm{~h}$. At the end of the observation time, all the surviving rats were sacrificed by decapitation.

In a second experiment, animals were treated with the same doses of extract as described before, and observed for 14 days for abnormal clinical signs and death. Rats were weighed on days 1, 7, and 14 after treatment (Rosidah et al., 2009), with food and water consumption measured daily. Rats were also submitted to an open field test to analyze changes in spontaneous locomotor activity at $3 \mathrm{~h}, 48 \mathrm{~h}$, and 14 days after the single dose treatments. All the surviving rats were sacrificed by decapitation on day 15.

\section{Open field test}

To analyze changes in spontaneous locomotor activity caused by the $S$. guaraniticum treatment, the animals were placed individually in an open field arena $(100 \times 100 \times 50 \mathrm{~cm})$ with black plywood walls and a white floor divided into 20 equal squares, as previously described (Broadhurst, 1960). The number of line crossings and rearings were measured over 5 min as well as the defecation rate.

\section{Collection of blood and organ samples}

At the end of both experiments ( $48 \mathrm{~h}$ and 14 days after the extract administration), the fasted animals were anesthetized by intraperitoneal injection of ketaminexylazine $(90-13 \mathrm{mg} / \mathrm{kg}$ ) and blood samples were collected by cardiac puncture into tubes respectively with or without EDTA for the hematological or biochemical analyses. Samples of the brain, liver, and kidney tissues were rapidly dissected, weighed, and placed on ice. The tissues were immediately homogenized in $10 \mathrm{mM}$ Tris- $\mathrm{HCl}$, ph 7.4 $(1 / 10 \mathrm{w} / \mathrm{v})$. The homogenates were centrifuged at $4,000 \mathrm{x}$ $\mathrm{g}$ at $4{ }^{\circ} \mathrm{C}$ for $10 \mathrm{~min}$ to yield a low-speed supernatant (S1) that was used for the determination of $\delta$-ALA-D, AChE, and catalase (CAT) activity, thiobarbituric acid reactive substances (TBARS) levels, and thiol content (NPSH). The protein content of the $\mathrm{S} 1$ also was measured (Peterson, 1977).

\section{Organ macroscopic examination and organ-to- body weight ratio}

The liver, stomach, kidneys, lung, heart, spleen, and small intestines of all animals were observed macroscopically in situ, based on the position, color, shape, size, and consistency of the organs. Thereafter, vital organs such as the right kidney, the liver and the 
spleen were necropsied and examined macroscopically for any lesions or abnormalities and the appearance of the individual organs in the treated and control groups was compared. Body and organ weights were measured and recorded. The relative organ weight of each animal was then calculated as follows: (absolute organ weight $\times$ $100 \%$ ) / body weight of rat on the day of sacrifice (Malathi, Gomaz, 2008).

\section{Biochemical and hematological analysis}

EDTA-blood samples were analyzed for white blood cell count (WBC), red blood cell count (RBC), hemoglobin $(\mathrm{Hb})$ concentration, hematocrit $(\mathrm{Ht})$, red blood cell distribution width (RDW), mean corpuscular volume $(\mathrm{MCV})$, mean corpuscular hemoglobin $(\mathrm{MCH})$, mean corpuscular hemoglobin concentration (MCHC), platelet and differential leukocyte counts. Hematological analyses were performed using a fully automated hematological analyzer (KX-21N, Sysmex, Japan).

Blood samples for biochemical analyses were allowed to clot and centrifuged at $3.400 \mathrm{rpm}$ for 10 min (CELM LS-3 Plus, Brazil). The serum was collected and analyzed for the following biochemistry parameters: alanine aminotransferase (ALT), aspartate aminotransferase (AST), alkaline phosphates (ALP), albumin, glucose, total cholesterol, triglycerides, urea, and creatinine. Measurements of biochemical parameters were performed using commercial kits and a semi-automated analyzer (BIO-2000, Bioplus, Brazil).

\section{Enzymatic assays}

The $\delta$-ALA-D activity in the liver, kidney, and cerebral cortex was assayed by Sassa method (1982). After a pre-incubation period, the enzymatic reaction was initiated by adding the substrate $\delta$-aminolevulinic acid and incubation was carried out at $37^{\circ} \mathrm{C}$ for $1 \mathrm{~h}$ for the liver and kidney, and $3 \mathrm{~h}$ for the cortical homogenate. The incubation was stopped by adding a $10 \%$ trichloroacetic acid solution with $10 \mathrm{mM} \mathrm{HgCl}_{2}$. Porphobilinogen (PBG), which is formed during the incubation period, was mixed with a modified Ehrlich's reagent, and the color developed was measured spectrophotometrically at $555 \mathrm{~nm}$ against a blank. The results were expressed as nmol $\mathrm{PBG} / \mathrm{mg}$ protein/h.

The AChE enzymatic assay in the cerebral cortex was determined by a modification of the Ellman et al. spectrophotometric method (1961), as previously described (Rocha, Emanuelli, Pereira, 1993). The reaction was initiated by adding $0.8 \mathrm{mM}$ of acetylthiocholine iodide ( $\mathrm{AcSCh})$ to the reaction mixture $(2 \mathrm{~mL}$ final volume), containing $100 \mathrm{mM}$ TFK, pH 7.5, and $1 \mathrm{mM}$ DTNB. The method is based on the formation of a yellow anion, 5,5'-dithio-bis-acid nitrobenzoic, measured by absorbance at $412 \mathrm{~nm}$ during $2 \mathrm{~min}$ of incubation at $25^{\circ} \mathrm{C}$. The enzyme activity was expressed in $\mu \mathrm{mol} \mathrm{AcSCh} / \mathrm{h} / \mathrm{mg}$ protein.

\section{Oxidative stress parameters}

Lipid peroxidation levels in liver, kidney and cerebral cortex tissues were estimated colorimetrically by measuring TBARS levels at $532 \mathrm{~nm}$, according to the method of Buege and Aust (1978), and presented in nmol of MDA/mg protein. NPSH content in tissues was determined according to Ellman (1959) based on the development of the color yellow with DTNB, which is measured at $412 \mathrm{~nm}$ and presented as $\mathrm{mmol} \mathrm{GSH} / \mathrm{mg}$ protein. CAT activity was assayed by the decomposition of hydrogen peroxide according to the method of Aebi (1984) and expressed as mmol $\mathrm{H}_{2} \mathrm{O}_{2}$ consumed/min/mg protein. In addition, the total serum antioxidant power was determined using the ferric reducing (FRAP) assay, a colorimetric method based on the reduction of a ferric tripyridyltriazine complex to its ferrous form (Benzie, Strain, 1996). The results are presented as $\mathrm{mM} \mathrm{Fe}^{2+}$.

\section{Statistical analysis}

The analyses were performed using Statistica for Windows, version 6.0 (StatSoft Inc. Tulsa, OK, USA). All data were analyzed using one way ANOVA followed by Duncan's multiple range test and presented as mean \pm standard error of mean (SEM). A value of $p<0.05$ was considered statistically significant for all analyses.

\section{RESULTS}

\section{Phytochemical screening of S. guaraniticum extract}

HPLC revealed the presence of gallic $\left(t_{R}=10.36 \mathrm{~min}\right)$, chlorogenic $\left(t_{R}=19.98 \mathrm{~min}\right)$ and ellagic acids $\left(t_{R}=28.15 \mathrm{~min}\right)$, catechin $\left(t_{R}=16.53 \mathrm{~min}\right)$, epicatechin $\left(t_{R}=32.08 \mathrm{~min}\right)$, rutin $\left(t_{R}=38.26 \mathrm{~min}\right)$, quercitrin $\left(t_{R}=42.31 \mathrm{~min}\right)$, isoquercitrin $\left(t_{R}=45.09 \mathrm{~min}\right)$, quercetin $\left(\mathrm{t}_{\mathrm{R}}=48.63 \mathrm{~min}\right)$ and kaempferol $\left(\mathrm{t}_{\mathrm{R}}=53.27 \mathrm{~min}\right)$ (Figure 1 and Table I).

\section{General clinical observations}

No death was recorded in any of the groups during the studied periods ( $48 \mathrm{~h}$ or 14 days). All treated animals 


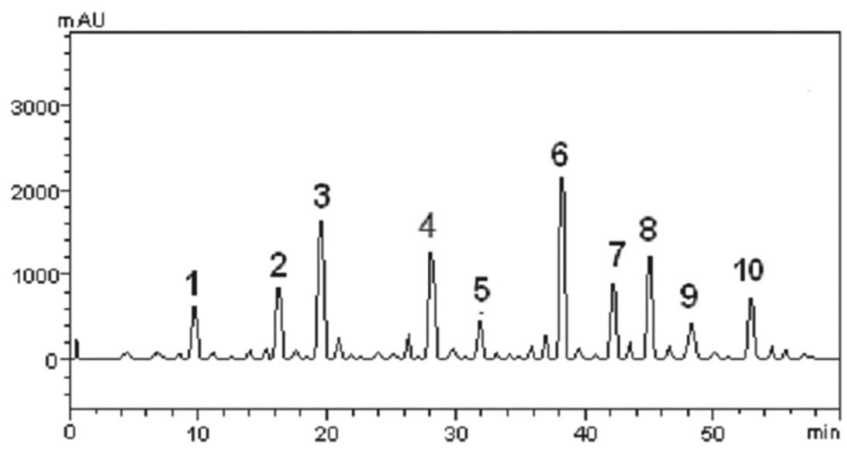

FIGURE 1 - Representative high performance liquid chromatography profile of Solanum guaraniticum leaf extract. Gallic acid (peak 1), catechin (peak 2), chlorogenic acid (peak 3), ellagic acid (peak 4), epicatechin (peak 5), rutin (peak 6), quercitrin (peak 7) isoquercitrin (peak 8), quercetin (peak 9), and kaempferol (peak 10).

TABLE I - Quantification of phenolic compounds found by HPLC analyses of Solanum guaraniticum leaf extract

\begin{tabular}{lc}
\hline \multirow{2}{*}{ Compounds } & S. guaraniticum extract \\
\cline { 2 - 2 } Gallic acid & $7.41 \pm 0.03$ \\
Catechin & $10.53 \pm 0.01$ \\
Chlorogenic acid & $26.85 \pm 0.06$ \\
Ellagic acid & $20.07 \pm 0.02$ \\
Epicatechin & $4.71 \pm 0.02$ \\
Rutin & $39.85 \pm 0.01$ \\
Quercitrin & $11.36 \pm 0.05$ \\
Isoquercitrin & $19.54 \pm 0.01$ \\
Quercetin & $5.17 \pm 0.01$ \\
Kaempferol & $9.73 \pm 0.05$ \\
\hline
\end{tabular}

Results are expressed as mean $\pm \operatorname{SEM}(n=3)$

showed piloerection immediately after dosing, which lasted approximately $15 \mathrm{~min}$. Thereafter, all animals behaved normally and no significant changes in general appearance or behavioral pattern were noted till the end of the observation times. Further, the consumption of food and water was similar between treated and control groups throughout the experiment (data not shown).

\section{Open field test}

In the open field test, the rats treated with $5,000 \mathrm{mg} / \mathrm{kg}$ of $S$. guaraniticum extract exhibited reduced total locomotor activity compared to the control group at
$48 \mathrm{~h}$ after dosing. When this parameter was evaluated at $3 \mathrm{~h}$ and 14 days after treatment, no differences between treated and control animals were found (Figure 2).

The group treated with $5,000 \mathrm{mg} / \mathrm{kg}$ of extract also showed reduced rearing frequencies in the vertical exploration test at $3 \mathrm{~h}$ after dosing. However, a dosedependent reduction in the number of rearings was observed in all treated rats at $48 \mathrm{~h}$ after $S$. guaraniticum administration. Interestingly, this effect was not observed at 14 days after treatment, when there was no difference between treated and control groups (Figure 2).

In relation to defecation frequency, which may indicate anxiety levels, none of the treated animals presented differences from the control group for number of fecal pellets (data not shown).

\section{Effect of the extract on organ weight and body weight gain}

Normal body weight gains were observed in all groups after 14 days of treatment (control $=46.4 \mathrm{~g} \pm 3.2$; group $1,250 \mathrm{mg} / \mathrm{kg}=45.2 \mathrm{~g} \pm 6.5$; group $2,500 \mathrm{mg} / \mathrm{kg}=$ $40.6 \mathrm{~g} \pm 4.1$; group $5,000 \mathrm{mg} / \mathrm{kg}=41 \mathrm{~g} \pm 10.4)$. No significant difference was observed in the relative organ weights of the treated rats when compared to the controls, at $48 \mathrm{~h}$ or 14 days after dosing (Table II). Organ examination did not reveal any abnormalities or gross lesions.

\section{Effect of the extract on hematological and biochemical parameters}

The hematological and biochemical profiles of the treated and control groups are presented in Tables III and IV, respectively. S. guaraniticum did not significantly alter either hematological or serum biochemical parameters as compared to the control animals.

\section{Enzymatic activities and oxidative stress parameters}

Acute treatment with $S$. guaraniticum extract did not promote any effects on the liver, kidney, or cerebral cortex, $\delta$-ALA-D activity, or on cerebral cortex AChE activity (Table V).

In the kidney, there was a decrease in TBARS levels only at day 14 after treatment. Notwithstanding, the extract did not alter NPSH levels or CAT activity in the organs of the treated animals. Moreover, no significant difference was observed in FRAP levels between the treated and control groups (Table VI). 


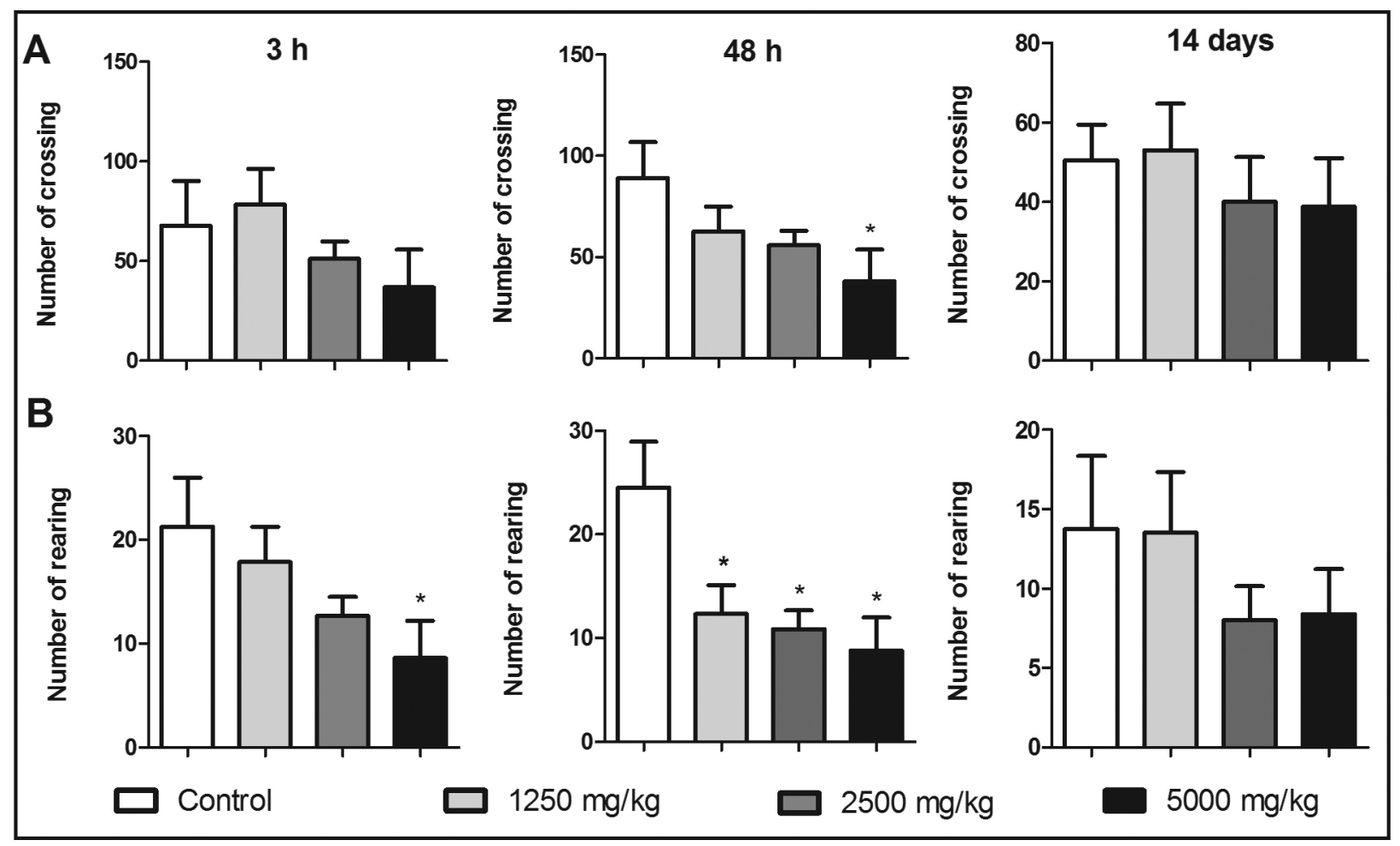

FIGURE 2 - Open field exploration. The effect of different single doses of $S$. guaraniticum extract in rats was evaluated after 3 h, $48 \mathrm{~h}$, and 14 days of treatment. (A) Number of crossings in 5 min. (B) Number of rearings in 5 min. Data is presented as mean \pm SEM of six rats per group. Asterisk denotes $\mathrm{p}<0.05$ compared to control group by one-way ANOVA followed by Duncan's test.

TABLE II - Body weight and organ body index of rats after $48 \mathrm{~h}$ and 14 days of S. guaraniticum treatment

\begin{tabular}{lcccc}
\hline & Control & $\mathbf{1 2 5 0} \mathbf{~ m g} / \mathbf{k g}$ & $\mathbf{2 5 0 0} \mathbf{~ m g} / \mathbf{k g}$ & $\mathbf{5 0 0 0} \mathbf{~ m g} / \mathbf{k g}$ \\
\hline $\mathbf{4 8 ~ h}$ & & & & \\
\hline Body weight (g) & $216.8 \pm 6.6$ & $216.3 \pm 11.6$ & $214.5 \pm 8.6$ & $205.2 \pm 7.1$ \\
Liver (\%) & $4.1 \pm 0.3$ & $4.23 \pm 0.2$ & $4.06 \pm 0.3$ & $3.87 \pm 0.2$ \\
Kidney (\%) & $0.42 \pm 0.01$ & $0.41 \pm 0.01$ & $0.43 \pm 0.02$ & $0.40 \pm 0.01$ \\
Spleen (\%) & $0.26 \pm 0.02$ & $0.27 \pm 0.01$ & $0.28 \pm 0.01$ & $0.26 \pm 0.01$ \\
\hline $\mathbf{1 4}$ days & & & $249.3 \pm 3$ \\
Body weight (g) & $277.2 \pm 7.3$ & $278.8 \pm 9.9$ & $3.54 \pm 0.1$ & $3.67 \pm 0.2$ \\
Liver (\%) & $3.66 \pm 0.1$ & $3.49 \pm 0.1$ & $0.36 \pm 0.01$ & $0.38 \pm 0.03$ \\
Kidney (\%) & $0.36 \pm 0.01$ & $0.34 \pm 0.01$ & $0.21 \pm 0.01$ & $0.21 \pm 0.03$ \\
Spleen (\%) & $0.21 \pm 0.01$ & $0.20 \pm 0.01$ &
\end{tabular}

Data are expressed as mean \pm SEM of six rats per group.

\section{DISCUSSION}

Though medicinal plants remain the first line of treatment for many ailments in developing countries where access to modern health facilities is limited, very little is generally known about their toxicity. Since there are just few published studies about its toxicological profile, this paradigm also applies to $S$. guaraniticum. Despite the fact that efficacy is one of the overriding criterions in the selection of medicinal plants for use in health care systems, safety should never be overlooked and formal toxicological evaluation of medicinal plants should be performed as part of the validation process (Chan, 2003). In this sense, the present acute oral toxicity 
TABLE III - Hematological profile of rats after $48 \mathrm{~h}$ and 14 days of S. guaraniticum treatment

\begin{tabular}{|c|c|c|c|c|}
\hline & Control & $1250 \mathrm{mg} / \mathrm{kg}$ & $2500 \mathrm{mg} / \mathrm{kg}$ & $5000 \mathrm{mg} / \mathrm{kg}$ \\
\hline \multicolumn{5}{|l|}{$48 \mathrm{~h}$} \\
\hline $\mathrm{WBC}\left(\mathrm{x} 10^{3} / \mathrm{mm}^{3}\right)$ & $8.63 \pm 1.28$ & $9.05 \pm 0.35$ & $7.90 \pm 1.42$ & $7.21 \pm 0.76$ \\
\hline $\mathrm{RBC}\left(\mathrm{x} 10^{6} / \mathrm{mm}^{3}\right)$ & $7.21 \pm 0.14$ & $7.08 \pm 0.08$ & $7.13 \pm 0.19$ & $7.35 \pm 0.16$ \\
\hline $\mathrm{Hb}(\mathrm{g} / \mathrm{dL})$ & $13.18 \pm 0.18$ & $13.33 \pm 0.11$ & $13.36 \pm 0.19$ & $13.42 \pm 0.25$ \\
\hline HCT (\%) & $42.03 \pm 0.67$ & $40.93 \pm 0.45$ & $41.76 \pm 1.08$ & $42.02 \pm 0.65$ \\
\hline MCV (fL) & $58.35 \pm 0.62$ & $57.82 \pm 0.47$ & $58.58 \pm 0.74$ & $57.15 \pm 0.58$ \\
\hline $\mathrm{MCH}(\mathrm{pg})$ & $18.28 \pm 0.29$ & $18.83 \pm 0.18$ & $18.68 \pm 0.52$ & $18.27 \pm 0.38$ \\
\hline $\mathrm{MCHC}(\mathrm{g} / \mathrm{dL})$ & $31.37 \pm 0.2$ & $32.58 \pm 0.14$ & $32.04 \pm 0.56$ & $31.93 \pm 0.41$ \\
\hline Platelets $\left(\mathrm{x} 10^{3} / \mathrm{mm}^{3}\right)$ & $1232 \pm 66.2$ & $1133 \pm 66.5$ & $1140 \pm 83$ & $1173 \pm 58.76$ \\
\hline RDW (\%) & $13.02 \pm 0.24$ & $13.33 \pm 0.34$ & $13 \pm 0.41$ & $13.88 \pm 0.64$ \\
\hline Eosinophils (\%) & $0.66 \pm 0.21$ & $0.83 \pm 0.3$ & $0.8 \pm 0.2$ & $1.5 \pm 0.71$ \\
\hline Monocytes (\%) & $2.66 \pm 0.33$ & $2.33 \pm 0.33$ & $2.6 \pm 0.4$ & $2.83 \pm 0.47$ \\
\hline Lymphocytes (\%) & $81.67 \pm 2.34$ & $72.17 \pm 6.97$ & $79.2 \pm 2.78$ & $76.83 \pm 2.6$ \\
\hline Neutrophils (\%) & $16.33 \pm 2.49$ & $23 \pm 7.12$ & $14.5 \pm 3.5$ & $19.17 \pm 2.28$ \\
\hline \multicolumn{5}{|l|}{14 days } \\
\hline$\overline{\mathrm{WBC}\left(\mathrm{x} 10^{3} / \mathrm{mm}^{3}\right)}$ & $10.05 \pm 1.05$ & $9.93 \pm 0.73$ & $8.53 \pm 1.05$ & $8.91 \pm 0.82$ \\
\hline $\mathrm{RBC}\left(\mathrm{x} 10^{6} / \mathrm{mm}^{3}\right)$ & $7.2 \pm 0.06$ & $7.4 \pm 0.27$ & $7.53 \pm 0.11$ & $7.85 \pm 0.14$ \\
\hline $\mathrm{Hb}(\mathrm{g} / \mathrm{dL})$ & $13.58 \pm 0.2$ & $13.43 \pm 0.33$ & $13.82 \pm 0.19$ & $14.17 \pm 0.26$ \\
\hline $\operatorname{HCT}(\%)$ & $41.65 \pm 0.56$ & $41.42 \pm 1.04$ & $42.85 \pm 0.38$ & $44.38 \pm 0.58 *$ \\
\hline MCV (fL) & $57.82 \pm 0.47$ & $56.07 \pm 0.76$ & $56.92 \pm 0.74$ & $56.57 \pm 0.72$ \\
\hline $\mathrm{MCH}(\mathrm{pg})$ & $18.83 \pm 0.21$ & $18.2 \pm 0.34$ & $18.37 \pm 0.44$ & $18.03 \pm 0.25$ \\
\hline $\mathrm{MCHC}(\mathrm{g} / \mathrm{dL})$ & $32.62 \pm 0.22$ & $32.45 \pm 0.18$ & $32.27 \pm 0.42$ & $31.92 \pm 0.35$ \\
\hline Platelets $\left(\mathrm{x} 10^{3} / \mathrm{mm}^{3}\right)$ & $1045 \pm 28$ & $1210 \pm 64.2$ & $955.7 \pm 104.6$ & $937.3 \pm 177$ \\
\hline RDW (\%) & $11.87 \pm 0.3$ & $13.03 \pm 0.4$ & $12.05 \pm 0.44$ & $12.05 \pm 0.21$ \\
\hline Eosinophils (\%) & $0.83 \pm 0.4$ & $1 \pm 0.51$ & $0.33 \pm 0.21$ & $0.5 \pm 0.34$ \\
\hline Monocytes (\%) & $1.5 \pm 0.42$ & $2 \pm 0.51$ & $2.16 \pm 0.47$ & $0.83 \pm 0.3$ \\
\hline Lymphocytes (\%) & $78.5 \pm 2.11$ & $79.67 \pm 2.6$ & $76 \pm 1.34$ & $82.17 \pm 1.32$ \\
\hline Neutrophils (\%) & $16.33 \pm 1.28$ & $17.50 \pm 2.48$ & $20.33 \pm 0.98$ & $15.33 \pm 0.95$ \\
\hline
\end{tabular}

White blood cell counts (WBC), red blood cells counts (RBC), hemoglobin (Hb), hematocrit (HCT), mean corpuscular volume (MCV), mean cell hemoglobin (MCH), mean cell corpuscular hemoglobin concentration (MCHC) and red blood cell distribution width (RDW). Data are expressed as mean \pm SEM. Asterisk denotes $\mathrm{p}<0.05$ compared to control group by one-way ANOVA followed by Duncan's test.

study has revealed the safety profile of $S$. guaraniticum leaf extract. On the basis of the presented results and under the conditions of this study, the lethal dose $\left(\mathrm{LD}_{50}\right)$ of $S$. guaraniticum extract after a single oral administration in male Wistar rats is expected to be more than $5.000 \mathrm{mg} / \mathrm{kg}$. Therefore, the extract may be characterized as nontoxic according to the classification proposed by Loomis and Hayes (Loomis, Hayes, 1996).

The reduction in the number of rearings and crossings may suggest that $S$. guaraniticum caused alterations in the activity of the central nervous system
(Morais, Barbosa-Filho, Almeida, 1998; Mora et al., 2005; Yasar et al., 2012). Further, it is interesting to note that the behavioral effects were more pronounced $48 \mathrm{~h}$ after treatment, and the behavior of the rats was similar to the controls at day 14 after treatment. In line with this, it is possible that the effect of $S$. guaraniticum extract may be delayed and short-lasting, since the animals showed normal behavior at the end of the second experiment.

General activity is an index for evaluating behavioral changes induced in animals, by not only physiological and genetic manipulation, but also by toxicological 
TABLE IV - Serum biochemical parameters of rats after $48 \mathrm{~h}$ and 14 days of S. guaraniticum treatment

\begin{tabular}{|c|c|c|c|c|}
\hline & Control & $1250 \mathrm{mg} / \mathrm{kg}$ & $2500 \mathrm{mg} / \mathrm{kg}$ & $5000 \mathrm{mg} / \mathrm{kg}$ \\
\hline \multicolumn{5}{|l|}{$48 \mathrm{~h}$} \\
\hline AST (U/L) & $95.83 \pm 4.7$ & $122.7 \pm 21.15$ & $115.7 \pm 14.4$ & $87.83 \pm 3.45$ \\
\hline ALT (U/L) & $45.67 \pm 3.73$ & $52.67 \pm 4.63$ & $51.17 \pm 7.78$ & $42.33 \pm 3.2$ \\
\hline $\operatorname{ALP}(\mathrm{U} / \mathrm{L})$ & $721.7 \pm 34.5$ & $878.70 \pm 97.5$ & $612.80 \pm 68.2$ & $677.3 \pm 75.9$ \\
\hline Urea (mg/dL) & $44.33 \pm 4.24$ & $48.00 \pm 3.27$ & $43.83 \pm 3.88$ & $47.33 \pm 4.31$ \\
\hline Creatinine (mg/dL) & $0.43 \pm 0.08$ & $0.53 \pm 0.04$ & $0.53 \pm 0.04$ & $0.49 \pm 0.06$ \\
\hline Albumin (g/dL) & $2.92 \pm 0.17$ & $2.87 \pm 0.13$ & $2.87 \pm 0.1$ & $3.07 \pm 0.29$ \\
\hline Glucose (mg/dL) & $156.6 \pm 9.6$ & $158.1 \pm 15.62$ & $150.6 \pm 9.18$ & $148.2 \pm 13.53$ \\
\hline Cholesterol (mg/dL) & $56 \pm 6.27$ & $57.12 \pm 6.66$ & $55.6 \pm 5.24$ & $56.62 \pm 4.38$ \\
\hline Triglyceride (mg/dL) & $202.8 \pm 12.76$ & $185.9 \pm 27.25$ & $181.2 \pm 22.66$ & $157.2 \pm 12.4$ \\
\hline \multicolumn{5}{|l|}{14 days } \\
\hline$\overline{\mathrm{AST}}(\mathrm{U} / \mathrm{L})$ & $94.67 \pm 8.26$ & $107.8 \pm 7.87$ & $103.4 \pm 9.35$ & $97.8 \pm 9.2$ \\
\hline $\operatorname{ALT}(\mathrm{U} / \mathrm{L})$ & $36.17 \pm 3$ & $42.17 \pm 3.69$ & $44.83 \pm 2.97$ & $43.4 \pm 5.11$ \\
\hline ALP (U/L) & $565 \pm 31.2$ & $513.8 \pm 49.9$ & $439 \pm 13.8$ & $624.8 \pm 39.6$ \\
\hline Urea (mg/dL) & $40 \pm 2.03$ & $35.83 \pm 1.86$ & $36.17 \pm 2.12$ & $36.2 \pm 2.17$ \\
\hline Creatinine (mg/dL) & $0.88 \pm 0.25$ & $0.56 \pm 0.04$ & $0.66 \pm 0.09$ & $0.58 \pm 0.17$ \\
\hline Albumin (g/dL) & $2.88 \pm 0.09$ & $2.63 \pm 0.12$ & $2.93 \pm 0.12$ & $3.04 \pm 0.17$ \\
\hline Glucose (mg/dL) & $194.6 \pm 8.04$ & $185.05 \pm 15.71$ & $180.6 \pm 15.13$ & $179 \pm 14.87$ \\
\hline Cholesterol (mg/dL) & $64.81 \pm 4$ & $65.47 \pm 4.34$ & $62.53 \pm 6.94$ & $69.72 \pm 5.2$ \\
\hline Triglyceride (mg/dL) & $187.5 \pm 26.81$ & $203.4 \pm 18.34$ & $217.8 \pm 10.13$ & $189.1 \pm 28.38$ \\
\hline
\end{tabular}

Aspartate transaminase (AST), alanine transaminase (ALT), alkaline phosphatase (ALP). Data are expressed as mean \pm SEM.

TABLE V - Tissue enzyme activity of rats after $48 \mathrm{~h}$ and 14 days of $S$. guaraniticum treatment

\begin{tabular}{lcccc}
\hline & Control & $\mathbf{1 2 5 0} \mathbf{~} \mathbf{g} / \mathbf{k g}$ & $\mathbf{2 5 0 0} \mathbf{~ m g} / \mathbf{k g}$ & $\mathbf{5 0 0 0} \mathbf{~ m g} / \mathbf{k g}$ \\
\hline $\mathbf{4 8 ~ h}$ & & & & \\
\hline Liver $\delta$-ALA-D & $8.61 \pm 0.57$ & $9.82 \pm 0.48$ & $9.67 \pm 0.91$ & $8.55 \pm 0.41$ \\
Kidney $\delta$-ALA-D & $3.66 \pm 0.12$ & $3.9 \pm 0.33$ & $3.96 \pm 0.32$ & $3.74 \pm 0.23$ \\
Cortex $\delta$-ALA-D & $1.1 \pm 0.08$ & $1.17 \pm 0.13$ & $1.32 \pm 0.13$ & $1.09 \pm 0.05$ \\
Cortex AChE & $0.68 \pm 0.06$ & $0.9 \pm 0.03$ & $0.81 \pm 0.1$ & $0.82 \pm 0.05$ \\
\hline $\mathbf{1 4}$ days & & & & \\
\hline Liver $\delta$-ALA-D & $11.01 \pm 0.32$ & $11.64 \pm 0.32$ & $11.04 \pm 0.28$ & $10.32 \pm 0.42$ \\
Kidney $\delta$-ALA-D & $4.58 \pm 0.34$ & $5.28 \pm 0.27$ & $4.24 \pm 0.31$ & $4.25 \pm 0.29$ \\
Cortex $\delta$-ALA-D & $1.85 \pm 0.44$ & $1.82 \pm 0.33$ & $1.65 \pm 0.33$ & $1.78 \pm 0.33$ \\
Cortex AChE & $0.62 \pm 0.14$ & $1.05 \pm 0.08$ & $0.93 \pm 0.12$ & $0.88 \pm 0.2$ \\
\hline
\end{tabular}

$\delta$-aminolevulinate dehydratase activity ( $\delta$-ALA-D; nmol porphobilinogen $(\mathrm{PBG}) / \mathrm{mg}$ protein/h). Acetylcholinesterase actitivty (AChE; $\mu \mathrm{mol} \mathrm{AcSCh} / \mathrm{h} / \mathrm{mg}$ of protein). Data are expressed as mean $\pm \mathrm{SEM}$.

interference (Karl, Pabst, Von Hörsten, 2003). Among the techniques used to assess general activity, the open field enables various behavioral parameters related to emotional, exploratory and motor behavior to be measured (Ribeiro de Assis et al., 2006). The decrease in locomotor and rearing frequencies caused by $S$. guaraniticum extract administration suggests depressant and/or motor disturbance. This effect is similar to symptoms of cattle intoxication caused by Solanum species (Rech et al., 2006; Riet-Correa et al., 1983; Paulovich et al., 2002), 
TABLE VI - Oxidative status of rats after $48 \mathrm{~h}$ and 14 days of S. guaraniticum treatment

\begin{tabular}{lcccc}
\hline & Control & $\mathbf{1 2 5 0} \mathbf{~} \mathbf{g} / \mathbf{k g}$ & $\mathbf{2 5 0 0} \mathbf{~} \mathbf{g} / \mathbf{k g}$ & $\mathbf{5 0 0 0} \mathbf{~ m g} / \mathbf{k g}$ \\
\hline $\mathbf{4 8} \mathbf{~ h}$ & & & & \\
\hline Liver TBARS & $0.54 \pm 0.11$ & $0.65 \pm 0.19$ & $0.46 \pm 0.07$ & $0.63 \pm 0.13$ \\
Kidney TBARS & $0.83 \pm 0.14$ & $0.76 \pm 0.11$ & $0.67 \pm 0.12$ & $0.54 \pm 0.07$ \\
Cortex TBARS & $2.66 \pm 0.36$ & $2.6 \pm 0.31$ & $2.62 \pm 0.13$ & $2.49 \pm 0.12$ \\
Liver NPSH & $2.79 \pm 1.18$ & $1.66 \pm 0.09$ & $1.57 \pm 0.27$ & $2.19 \pm 0.22$ \\
Kidney NPSH & $2.51 \pm 0.46$ & $3.38 \pm 0.33$ & $3.23 \pm 0.68$ & $3.22 \pm 0.4$ \\
Cortex NPSH & $9.11 \pm 2.91$ & $8.09 \pm 2.19$ & $7.6 \pm 1.11$ & $8.9 \pm 2.94$ \\
Liver CAT & $10.55 \pm 0.52$ & $10.98 \pm 0.74$ & $8.78 \pm 0.25$ & $9.87 \pm 0.29$ \\
Kidney CAT & $5.97 \pm 0.2$ & $5.92 \pm 0.2$ & $5.70 \pm 0.51$ & $5.59 \pm 0.41$ \\
Cortex CAT & $0.93 \pm 0.21$ & $0.89 \pm 0.25$ & $0.61 \pm 0.09$ & $0.55 \pm 0.08$ \\
Serum FRAP & $0.46 \pm 0.03$ & $0.53 \pm 0.07$ & $0.55 \pm 0.08$ & $0.51 \pm 0.09$ \\
\hline $\mathbf{1 4}$ days & & & & \\
\hline Liver TBARS & $0.45 \pm 0.12$ & $0.69 \pm 0.2$ & $0.47 \pm 0.08$ & $0.59 \pm 0.23$ \\
Kidney TBARS & $1.50 \pm 0.29$ & $0.83 \pm 0.08^{*}$ & $0.69 \pm 0.1 * *$ & $0.89 \pm 0.08^{*}$ \\
Cortex TBARS & $4.04 \pm 0.89$ & $3.03 \pm 0.89$ & $2.39 \pm 0.5$ & $2.75 \pm 0.32$ \\
Liver NPSH & $3.24 \pm 0.94$ & $2.38 \pm 0.7$ & $2.60 \pm 0.4$ & $2.96 \pm 0.75$ \\
Kidney NPSH & $3.41 \pm 0.47$ & $2.73 \pm 0.35$ & $2.69 \pm 0.32$ & $3.73 \pm 0.41$ \\
Cortex NPSH & $5.18 \pm 0.33$ & $6.53 \pm 0.72$ & $7.35 \pm 1.03$ & $7.44 \pm 0.94$ \\
Liver CAT & $8.52 \pm 0.3$ & $8.46 \pm 0.23$ & $8.20 \pm 0.14$ & $8.28 \pm 0.41$ \\
Kidney CAT & $4.87 \pm 0.12$ & $4.58 \pm 0.2$ & $4.72 \pm 0.15$ & $4.79 \pm 0.18$ \\
Cortex CAT & $1.57 \pm 0.6$ & $1.59 \pm 0.49$ & $1.17 \pm 0.39$ & $1.03 \pm 0.3$ \\
Serum FRAP & $0.47 \pm 0.04$ & $0.56 \pm 0.04$ & $0.56 \pm 0.02$ & $0.48 \pm 0.02$ \\
\hline Thiobari & & & \\
\hline
\end{tabular}

Thiobarbituric acid reactive substances (TBARS; nmol MDA (malondialdehyde)/mg protein). Non-protein thiol groups (NPSH; $\mathrm{mmol} \mathrm{GSH} / \mathrm{mg}$ protein). Catalase (CAT; $\mathrm{mmol} \mathrm{H}_{2} \mathrm{O}_{2}$ consumed/min/mg protein). Ferric reducing power (FRAP; $\mathrm{mM} \mathrm{Fe}{ }^{2+}$ ). Data are expressed as mean \pm SEM. ${ }^{*} \mathrm{p}<0.05,{ }^{*} \mathrm{p}<0.01$ compared to control group by one-way ANOVA followed by Duncan's test.

which includes locomotive incoordination and loss of equilibrium. Although this study does not present microscopic evaluation of brain tissues, these results should be further investigated prior to indication of this plant as a phytotherapeutic agent. Further, it is quite possible that the extract's compounds are related to this activity, since it is known that a wide range of phenolic compounds interact directly with neurotransmitter systems and exert depressant effects (Kennedy, Wightman, 2011).

The similarity between the treated and control groups for food and water consumption and weight gain during the study period, as well as the compared hematological and biochemical profiles indicate that $S$. guaraniticum treatment did not cause significant adverse effects. Moreover, the treatment did not modify significantly the antioxidant status in animal tissues or serum, as assessed by the TBARS, NPSH and FRAP levels, and CAT activity, this excepting the kidneys where TBARS levels were decreased. The results suggest that the extract could have renal protective action.

Similarly, previous results in our laboratory have demonstrated the in vitro inhibitory effect of the extract on erythrocyte and brain $\delta$-ALA-D activity, suggesting a hematologic and neurotoxic effect (Bonfanti el al., 2013, 2014). However, the effect was not observed after in vivo acute treatment. This might be explained by the complex pharmacokinetic and pharmacodynamic characteristics of plant extracts (Rabbani, Sajjadi, Mohammadi, 2008; Akindele, Adeyemi, 2010). Plant extracts are composed of various components, with mostly unknown pharmacological and dose-response data (Ahmed, Azmat, Azeem, 2004). The numerous bioactivities found in in vitro studies are not always meaningful to human health because the bioavailability of the natural product is often limited and only low plasma concentrations are detected in vivo (Villegas, Sánchez-Fidalgo, Alarcón de la Lastra, 2008). 
In this context, in vivo studies are helpful in clarifying the effective biological properties of a plant's constituents thru considering metabolism and pharmacokinetics.

Toxicity studies in appropriate animal models are commonly used to assess potential health risks to humans. This is a key stage in ensuring the safety of drugs and an acute toxicity study is just one of the many types of toxicity tests that are used for such purposes (Asare et al., 2011). The fact that no lethal toxic effects were observed in the $S$. guaraniticum acute toxicity study indicates that plant preparations are safe for short-term treatments; and this low toxicity may have been responsible for its widespread use in varied ethno-therapeutic interventions. However, this assertion of safety may not be applicable to herbal preparation taken for a long period. To add further safety information a chronic toxicity study is recommended.

\section{CONCLUSION}

In conclusion, this study provides valuable data on the acute oral toxicity profile of $S$. guaraniticum. Based on the toxicological parameters evaluated, it can be concluded that this medicinal plant is not acutely toxic yet appears to possess some action on the general behavior of rats, a biological property that deserves greater attention. The results presented may be helpful for therapeutic decisions with respect to the toxicology of $S$. guaraniticum extract, and should be useful for any future in vivo or clinical study of this medicinal plant.

\section{ACKNOWLEDGMENTS}

The authors acknowledge the doctoral fellowship to Gabriela Bonfanti given by the Fundação Coordenação de Aperfeiçoamento de Pessoal de Nível Superior (CAPES), as well as the Federal University of Santa Maria (UFSM), RS, Brazil, for financial support.

\section{CONFLICT OF INTEREST}

The authors declare that they have no conflicts of interest to disclose.

\section{REFERENCES}

AEBI, H. Catalase in vitro. Methods Enzymol., v.105, p.121126, 1984.

AHMED, M.; AZMAT, A.; AZEEM, M.A. Dose-response curve of Somina (Herbal preparation): a study on frog heart. Pak. J. Pharmacol., v.21, n.2, p.19-22, 2004.
AKINDELE, A.; ADEYEMI, O. Anxiolytic and sedative effects of Byrsocarpus coccineus Schum. and Thonn. (Connaraceae) extract. Int. J. Appl. Res. Nat. Prod., v.3, n.1, p.28-36, 2010.

ANDRADE, F.; ALBUQUERQUE, C.A.C.; MARASCHIN, M.; SILVA, E.L. Safety assessment of yerba mate (Ilex paraguariensis) dried extract: results of acute and 90 days subchronic toxicity studies in rats and rabbits. Food Chem. Toxicol., v.50, n.2, p.328-334, 2012.

ASARE, G.A.; ADDO, P.; BUGYEI, K.; GYAN, B.; ADJEI, S.; OTU-NYARKO, L.S.; WIREDU, E.K.; NYARKO, A. Acute toxicity studies of aqueous leaf extract of Phyllanthus niruri. Interdiscipl. Toxicol., v.4, n.4, p.206-210, 2011.

BAKER, D.C.; KEELER, R.F.; GAFFIELD, W. Toxicosis from steroidal alkaloids of Solanum species: toxicology of plant and fungal compounds. In: KEELER, R.F.; TU, A.T., eds. Handbook of natural toxins. New York: Marcel Dekker, 1991. p.589-610.

BENZIE, I.F.; STRAIN, J.J. The ferric reducing ability of plasma (FRAP) as a measure of antioxidant power: the FRAP assay. Anal. Biochem., v.239, n.1, p.70-76, 1996.

BOHS, L. Major clades in Solanum based on $n d h \mathrm{~F}$ sequences. In: KEATING, R.C.; HOLLOWELL, V.C.; CROAT, T.B., eds. A festschrift for William G. D'Arcy: the legacy of a taxonomist. Saint Louis: Missouri Botanical Garden Press, 2005. p.27-49. (Monographs in systematic botany from the Missouri Botanical Garden, 104).

BONFANTI, G.; BITENCOURT, P.R.; DE BONA, K.S.; SILVA, P.S.; JANTSCH, L.B.; PIGATTO, A.S.; BOLIGON, A.; ATHAYDE, M.L.; GONÇALVES, T.L.; MORETTO, M.B. Syzygium jambos and Solanum guaraniticum show similar antioxidant properties but induce different enzymatic activities in the brain of rats. Molecules, v.18, n.8, p.9179-9194, 2013.

BONFANTI, G.; DE BONA, K.S.; DE LUCCA, L.; JANTSCH, L.; PIGATTO, A.S.; BOLIGON, A.A.; ATHAYDE, M.L.; MORETTO, M.B.; GONÇALVES, T.L. Delta-ALA-D inhibitory potential and protective action of Syzygium jambos and Solanum guaraniticum leaf extracts on oxidatively stressed erythrocytes. Redox Rep., v.19, n.5, p.206-213, 2014. 
BROADHURST, P.L. Experiments in psychogenetics, application on biometrical genetics to the inheritance of behavior. In: EYSENCK, H.J., ed. Experiments in personality. London: Routledge \& Kegan Paul, 1960. v.1, p.1-120.

BUEGE, J.A.; AUST, S.D. Microsomal lipid peroxidation. Methods Enzymol., v.52, p.302-310, 1978.

CHAN, K. Some aspects of toxic contaminants in herbal medicines. Chemosphere, v.52, n.9, p.1361-1371, 2003.

CORRÊA, M.P. Dicionário das plantas úteis do Brasil e das exóticas cultivadas. [S.1.]: Ministério da Agricultura, Instituto Brasileiro de Desenvolvimento Florestal, 1984. v.3.

COSTA, O.A. Jurubeba. Rev. Bras. Farm., v.21, p.404-416, 1940.

EIDI, A.; EIDI, M.; ESMAEILI, E. Antidiabetic effect of garlic (Allium sativum L.) in normal and streptozotocin-induced diabetic rats. Phytomedicine, v.13, n.9/10, p.624-629, 2006.

ELLMAN, G.L. Tissue sulfhydryl groups. Arch. Biochem. Biophys., v.82, n.1, p.70-77, 1959.

ELLMAN, G.L.; COURTNEY, K.D.; ANDRES Jr., V.; FEATHERSTONE, R.M. A new and rapid colorimetric determination of acetylcholinesterase activity. Biochem. Pharmacol., v.7, n.2, p.88-95, 1961.

HOR, S.Y.; AHMAD, M.; FARSI, E.; LIM, C.P.; ASMAWI, M.Z.; YAM, M.F. Acute and subchronic oral toxicity of Coriolus versicolor standardized water extract in SpragueDawley rats. J. Ethnopharmacol., v.137, n.3, p.1067-1076, 2011.

JADHAV, S.J.; SHARMA, R.P.; SALUNKHE, D.K. Naturally occurring toxic alkaloids in foods. Crit. Rev. Toxicol., v.9, n.1, p.21-104, 1981.

KARL, T.; PABST, R.; VON HÖRSTEN, S. Behavioral phenotyping of mice in pharmacological and toxicological research. Exp. Toxicol. Pathol., v.55, n.1, p.69-83, 2003.

KENNEDY, D.O.; WIGHTMAN, E.L. Herbal extracts and phytochemicals: pant secondary metabolites and the enhancement of human brain function. Adv. Nutr., v.2, n.1, p.32-50, 2011.
LOOMIS, T.A.; HAYES, A.W. Loomis's essentials of toxicology. 4.ed. San Diego: Academic Press, 1996. 282 p.

MALATHI, R.; GOMAZ, P. Evaluation of preliminary toxicity studies on the methanolic leave extract of Tylophora asthmatica in experimental rats. J. Pharmacol. Toxicol., v.3, n.1, p.34-40, 2008.

MORA, S.; DÍAZ-VÉLIZ, G.; MILLÁN, R.; LUNGENSTRASS, H.; QUIRÓS, S.; COTO-MORALES, T.; HELLIÓNIBARROLA, M.C. Anxiolytic and antidepressant-like effects of the hydroalcoholic extract from Aloysia polystachya in rats. Pharmacol., Biochem. Behav., v.82, n.2, p.373-378, 2005.

MORAIS, L.C.S.L.; BARBOSA-FILHO, J.M.; ALMEIDA, R.N. Central depressant effects of reticuline extracted from Ocotea duckei in rats and mice. J. Ethnopharmacol., v.62, n.1, p.57-61, 1998.

NOGUEIRA, C.W.; BORGES, V.C.; ZENI, G.; ROCHA, J.B.T. Organochalcogens effects on $\delta$-aminolevulinate dehydratase activity from human erythrocytic cells in vitro. Toxicology, v.191, n.2/3, p.169-178, 2003.

OECD. Organization for Economic Cooperation and Development. OECD Guidelines for the testing of chemicals: acute oral toxicity - acute toxic class method. Paris: Organization for Economic Cooperation and Development, 2001. 14p. (OECD/OCDE Test n.423). Available at: https://ntp.niehs.nih.gov/iccvam/suppdocs/ feddocs/oecd/oecd_gl423.pdf>. Accessed on: April 2015.

OECD. Organization for Economic Cooperation and Development. OECD Guidelines for the testing of chemicals: repeated dose 28-day oral toxicity study in rodents. Paris: Organization for Economic Cooperation and Development, 2008. 13p. (OECD/OCDE Test n.407). Available at: <http://www.oecd-ilibrary.org/docserver/ download/9740701e.pdf?expires=1462907307\&id=id\&a ccname $=$ guest\&checksum $=4$ C051DAF7247577C6E48A 97B48885D63>. Accessed on: April 2015.

PAULOVICH, F.B.; PORTIANSKY, E.L.; GIMENO, E.J.; SCHILD, A.L.; MENDEZ, M.C.; RIET-CORREA, F. Lectin histochemical study of lipopigments present in the cerebellum of Solanum fastigiatum var. fastigiatum intoxicated cattle. J. Vet. Med., A, v.49, n.9, p.473-477, 2002. 
PAYNE, J.F.; MATHIEW, A.; MELVIN, W.; FANCEY, L.L. Acetylcholinesterase, an old biomarker with a new future? Field trials in association with two urban rivers and a paper mill in Newfoundland. Mar. Pollut. Bull., v.32, n.2, p.225231,1996 .

PETERSON, G.L. A simplification of the protein assay method of Lowry et al. which is more generally applicable. Anal. Biochem., v.83, n.2, p.346-356, 1977.

POHANKA, M. Cholinesterases, a target of pharmacology and toxicology. Biomed. Pap. Med. Fac. Univ. Palacký, Olomouc, Czech. Repub., v.155, n.3, p.219-229, 2011.

RABBANI, M.; SAJJADI, S.; MOHAMMADI, A. Evaluation of the anxiolytic effect of Nepeta persica Boiss in mice. Evid. Based Complement. Alternat. Med., v.5, n.2, p.181186, 2008.

RECH, R.R.; RISSI, D.R.; RODRIGUES, A.; PIEREZAN, F.; PIAZER, J.V.M.; KOMMERS, G.D.; BARROS, C.S.L. Intoxicação por Solanum fastigiatum (Solanaceae) em bovinos: epidemiologia, sinais clínicos e morfometria das lesões cerebelares. Pesq. Vet. Bras., v.26, n.3, p.183-189, 2006.

RIBEIRO DE ASSIS, J.C.; SUFFREDINI, I.B.; MORENO, P.R.; YOUNG, M.C.; VARELLA, A.D.; YOUNES, R.N.; BERNARDI, M.M. Analysis of the toxic potential of Palicourea corymbifera (Mull Arg.) Standl. in laboratory animals. Res. Vet. Sci., v.80, n.2, p.209-217, 2006.

RIET-CORREA, F.; MÉNDEZ, M.C.; SCHILD, A.L.; SUMMERS, B.A.; OLIVEIRA, J.A. Intoxication by Solanum fastigiatum var. fastigiatum as a cause of cerebellar degeneration of cattle. Cornell Vet., v.73, n.3, p.240-256, 1983.

ROCHA, J.B.; EMANUELLI, T.; PEREIRA, M.E. Effects of early undernutrition on kinetic parameters of brain acetylcholinesterase from adult rats. Acta Neurobiol. Exp., v.53, n.3, p.431-437, 1993.

ROSIDAH; YAM, M.F.; SADIKUN, A.; AHMAD, M.; AKOWUAH, G.A.; ASMAWI, M.Z. Toxicology evaluation of standardized methanol extract of Gynura procumbens. J. Ethnopharmacol., v.123, n.2, p.244-249, 2009.
SABIR, S.M.; ROCHA, J.B.T. Antioxidant and hepatoprotective activity of aqueous extract of Solanum fastigiatum (false "Jurubeba") against paracetamol-induced liver damage in mice. J. Ethnopharmacol., v.120, n.2, p.226-232, 2008.

SASSA, S. Delta-aminolevulinic acid dehydratase assay. Enzyme, v.28, n.2/3, p.133-145, 1982.

SCHETINGER, M.R.C.; PORTO, N.M.; MORETTO, M.B.; MORSCH, V.M.; ROCHA, J.B.T.; VIEIRA, V.; MORO, F.; NEIS, R.T.; BITTENCOURT, S.; BONACORSO, H.G.; ZANATTA, N. New benzodiazepines alter acetylcholinesterase and ATPase activities. Neurochem. Res., v.25, n.7, p.949-955, 2000.

SHENOUDA, J.; GREEN, P.; SULTATOS, L. An evaluation of the inhibition of human butyrylcholinesterase and acetylcholinesterase by the organophosphate chlorpyrifos oxon. Toxicol. Appl. Pharmacol., v.241, n.2, p.135-142, 2009

SIMÕES, C.M.O.; FALKENBERG, M.; MENTZ, L.A.; SCHENKEL, E.P.; AMOROS, M.; GIRRE, L. Antiviral activity of south Brazilian medicinal plant extracts. Phytomedicine, v.6, n.3, p.205-214, 1999.

SOUZA, A.C.G.; LUCHESE, C.; SANTOS NETO, J.S.; NOGUEIRA, C.W. Antioxidant effect of a novel class of telluroacetilene compounds: studies in vitro and in vivo. Life Sci., v.84, n.11/12, p.351-357, 2009.

STEHMANN, J.R.; MENTZ, L.A.; AGRA, M.F.; VIGNOLISILVA, M.; GIACOMIN, L. Solanaceae. In: Lista de espécies da Flora do Brasil. Rio de Janeiro: Jardim Botânico do Rio de Janeiro, 2012. Available at: <http://floradobrasil. jbrj.gov.br/jabot/listaBrasil/PrincipalUC/PrincipalUC.do ;jsessionid=881E70462293A552A0EC8BF5902633B7>. Accessed on: 08 Oct. 2013.

VILLEGAS, I.; SÁNCHEZ-FIDALGO, S.; ALARCÓN DE LA LASTRA, C. New mechanisms and therapeutic potential of curcumin for colorectal cancer. Mol. Nutr. Food Res., v.52, n.9, p.1040-1061, 2008.

WORLD HEALTH ORGANIZATION. WHO. WHO guidelines on safety monitoring of herbal medicines in pharmacovigilance systems. Geneva: World Health Organization, 2008. 
WORLD HEALTH ORGANIZATION. WHO. The world medicines situation 2011: traditional medicines: global situation issues and challenges. Geneva: World Health Organization, 2011.

YASAR, S.N.; CAN, O.D.; OZTURK, N.; SAGRATINI, G.; RICCIUTELLI, M.; VITTORI, S.; MAGGI, F. Central nervous system activities of Hypericum origanifolium extract via gabaergic and opioidergic mechanisms. Phytother. Res., v.27, n.6, p.877-884, 2012.
ZADRA, M.; PIANA, M.; BRUM, T.F.; BOLIGON, A.A.; FREITAS, R.B.; MACHADO, M.M.; STEFANELLO, S.T.; SOARES, F.A.A.; ATHAYDE, M.L. Antioxidant activity and phytochemical composition of the leaves of Solanum guaraniticum A. St.-Hil. Molecules, v.17, n.11, p.1256012574, 2012.

Received for publication on $20^{\text {th }}$ April 2015 Accepted for publication on $27^{\text {th }}$ October 2015 
